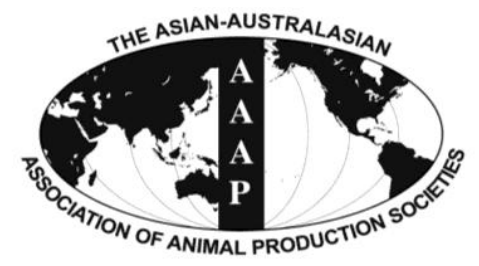

Asian Australas. J. Anim. Sci.

Vol. 26, No. 5 : 705-710 May 2013

http://dx.doi.org/10.5713/ajas.2012.12633

www.ajas.info

pISSN $1011-2367$ elSSN 1976-5517

\title{
Influence of Dietary Fat Source on Growth Performance Responses and Carcass Traits of Broiler Chicks
}

\author{
Mohammadreza Poorghasemi, Alireza Seidavi*, Ali Ahmad Alaw Qotbi, \\ Vito Laudadio ${ }^{1}$ and Vincenzo Tufarelli ${ }^{1}$ \\ Department of Animal Science, Rasht Branch, Islamic Azad University, Rasht, Iran
}

\begin{abstract}
This study was conducted to determine the effects of three different fat sources and their combination on growth performance, carcass traits and intestinal measurements of broiler chickens reared to $42 \mathrm{~d}$ of age. Two hundred day-old male broiler chicks (Ross 308) were randomly assigned to one of five treatments with four replicates of 10 chicks based on a completely randomized design. The dietary treatments consisted of $4 \%$ added fat from three different sources and their combination as follows: $\mathrm{T}$, diet containing $4 \%$ tallow; CO, diet containing $4 \%$ canola oil; SFO, diet containing $4 \%$ sunflower oil; TCO, diet containing $2 \%$ tallow $+2 \%$ canola oil; TSFO, diet containing $2 \%$ tallow $+2 \%$ sunflower oil. Dietary fat type affected significantly BW and gain as well as feed efficiency in birds fed the TCO diets compared with those fed the other diets. Dietary fat type also modified meat yield, resulting in a higher breast and drumstick yields in the birds fed TCO and TSFO diets, respectively. Most of internal organ relative weights and small intestine measurements were not influenced by dietary treatments, except for the abdominal fat pad weight that was lower in birds fed SFO and for small intestinal length that was influenced by fat source. Results from the current study suggested that the supplementation with a combination of vegetable and animal fat sources in broiler diet supported positively growth performance and carcass parameters. (Key Words: Broiler, Fats, Performance, Carcass Traits)
\end{abstract}

\section{INTRODUCTION}

The inclusion of fat and oil is a common practice in modern poultry production to increase the energy content of diet. In addition, dietary fat reduced passage rate of the digesta through the gastrointestinal trait, allowing for better nutrient absorption and utilization (Peebles et al., 2000; Baião and Lara, 2005; Latshaw, 2008). Digestibility of dietary fats is affected by the fatty acid profiles, and several studies have shown better utilization of unsaturated fats leading to a higher metabolizable energy than saturated fats (Celebi and Utlu, 2004). It was reported that fat metabolism and deposition in poultry can be affected by different dietary fats (Snaz et al., 2000; Pesti et al., 2002). The addition of fat to diet, besides supplying energy, improves the absorption of fat-soluble vitamins, diminishes the pulverulence, increases the palatability of the rations. By increasing fat sources to broiler diet, the amount of feed

\footnotetext{
* Corresponding Author: Alireza Seidavi. Tel: +981314224069, Fax: +981314223621, E-mail: alirezaseidavi@iaurasht.ac.ir ${ }^{1}$ DETO-Section of Veterinary and Animal Production, University of Bari ‘Aldo Moro', 70010 Valenzano, Bari, Italy. Submitted Nov. 11, 2012; Accepted Jan. 11, 2013; Revised Jan. 28, 2013
}

intake decreased and feed efficiency was improved (Jeffri et al., 2010).

To date, a number of different fat sources are available for poultry from both animal and vegetable sources and from the rendering industry (Sanz et al., 2000). It was observed that the replacement of tallow by vegetable fats rich in polyunsaturated fatty acids like sunflower oil, soybean oil, or linseed oil resulted in a decrease of abdominal fat deposition in broilers (Newman et al., 2002; Ferrini et al., 2008; Wongsuthavas et al., 2008). In a study, Sanz et al. (1999) fed broilers with sunflower oil or tallow in diet and found that the utilization of saturated fats resulted in greater abdominal fat deposits compared to birds fed unsupplemented diet. Newman et al. (2002) reported in broilers fed $8 \%$ beef tallow in the diet a significant depression of feed efficiency compared to birds fed sunflower or fish oil. Furthermore, adding 3\% of canola oil in broiler diet resulted in a significant improvement in body weight and feed conversion ratio when compared to birds fed animal fat (Newman et al., 2002); however, no significant difference was found in carcass traits and organ weight between groups. On the other hand, Shahryar et al. (2011) found that the addition of $6 \%$ animal fat in broiler 
diet led to an increase of abdominal fat and gizzard weight in comparison with those of birds fed unsupplemented diets.

Therefore, the present trial was conducted to evaluate the effect of three different fat sources (tallow, canola oil and sunflower oil) and their combination on growth performance, carcass traits and intestinal measurements of broiler chickens.

\section{MATERIAL AND METHODS}

\section{Husbandry, experimental design and diets}

The experiment was conducted during 2011 in a poultry research facility situated in the Islamic Azad University, Rasht Branch, Rasht, Iran. The trial lasted $42 \mathrm{~d}$ and pens, with dimensions of $2 \times 1 \mathrm{~m}$ and $1 \mathrm{~m}$ height, were randomly assigned to five dietary treatments with each having four replicates of 10 birds.

In preparation to trial, the poultry facility was accurately cleaned and rinsed using pressurized water in order to disinfect the environment. The hall was gasified after drinker and feeder installation and $24 \mathrm{~h}$ before broilers allocation. A total of 200 d-old male chicks (Ross-308), from a commercial hatchery, were raised in a conventional environment. The study was conducted in a completely randomized design with five treatments. Each diet (treatment) was replicated four times, with each replicate comprising one pen of 10 birds. The average body weight (BW) of broilers was on $43.5 \mathrm{~g}$. Chicks were vaccinated following the standard vaccination schedule, and in order to reduce the stress caused by vaccination to birds, $24 \mathrm{~h}$ before and after vaccination, a multi-electrolyte solution was added in drinking water. Poultry facilities had thermostatically controlled curtains and cross-ventilation as well as lighting program (Laudadio et al., 2012). Pens were equipped with a pan feeder, a manual drinker and wood shavings. Drinkers were regularly washed to prevent fecal and microbial contaminations.

A three phase feeding regime consisting of starter ( 1 to $14 \mathrm{~d}$ ), grower (14 to $28 \mathrm{~d}$ ) and finisher (28 to $42 \mathrm{~d}$ ) diets were used in the study. Up to slaughtering age (42 d), birds were fed five diets containing different fat sources formulated to meet or exceed broiler nutrient requirements (NRC, 1994). The dietary treatments consisted of $4 \%$ added fat from three different sources and their combination as follows: $\mathrm{T}$, diet containing $4 \%$ tallow; $\mathrm{CO}$, diet containing $4 \%$ canola oil; SFO, diet containing $4 \%$ sunflower oil; TCO, diet containing $2 \%$ tallow $+2 \%$ canola oil; TSFO, diet containing $2 \%$ tallow $+2 \%$ sunflower oil. Ingredients and chemical composition of the basal diets are shown in Table 1 and 2, respectively. Diet samples were ground in a hammer mill with a $1 \mathrm{~mm}$ screen and analysed in triplicate for dry matter (DM, method 945.15), crude protein (Kjeldahl $\mathrm{N} \times 6.25$, method 990.03), ether extract (method
Table 1. Ingredients and chemical analysis of experimental diets fed to broilers

\begin{tabular}{lrrr}
\hline Ingredients & \multicolumn{3}{c}{ Experimental diets } \\
\cline { 2 - 4 }$(\%$ as-fed basis $)$ & Starter & Grower & Finisher \\
\hline Corn & 54.50 & 58.50 & 62.70 \\
Soybean meal (48\% CP) & 37.50 & 33.50 & 29.50 \\
Fat $^{1}$ & 4.00 & 4.00 & 4.00 \\
Dicalcium phosphate $_{\text {Calcium carbonate }}$ & 1.60 & 1.50 & 1.50 \\
Vitamin-mineral premix & 2.20 & 1.20 & 1.10 \\
Sodium chloride & 0.60 & 0.60 & 0.60 \\
DL-methionine & 0.23 & 0.26 & 0.25 \\
Sodium bicarbonate & 0.18 & 0.21 & 0.15 \\
L-lysine $\mathrm{HCl}$ & 0.12 & 0.14 & 0.10 \\
\hline
\end{tabular}

${ }^{1}$ Each diet contained one of the following fat sources: $\mathrm{T}=4 \%$ tallow; $\mathrm{CO}$ $=4 \%$ canola oil; $\mathrm{SFO}=4 \%$ sunflower oil; $\mathrm{TCO}=2 \%$ tallow $+2 \%$ canola oil; $\mathrm{TSFO}=2 \%$ tallow $+2 \%$ sunflower oil.

${ }^{2}$ Supplied per kilogram of diet: vitamin A 11,000 IU; vitamin E, $50 \mathrm{mg}$; vitamin D 2,200 IU; niacin $35.0 \mathrm{mg}$; D-pantothenic acid $12 \mathrm{mg}$; riboflavin $3.63 \mathrm{mg}$; pyridoxine $3.5 \mathrm{mg}$; thiamine $2.4 \mathrm{mg}$; folic acid 1.4 $\mathrm{mg}$; biotin $0.15 \mathrm{mg}$; vitamin B $0.03 \mathrm{mg}$; Mn $60 \mathrm{mg}$; Zn $40 \mathrm{mg}$; Fe 1,280 $\mathrm{mg}$; Cu $8 \mathrm{mg}$; I $0.3 \mathrm{mg}$; Se $0.2 \mathrm{mg}$.

945.16) and ash (method 967.05) according to AOAC (2000). The metabolisable energy (ME) of the diets was estimated using the Carpenter and Clegg equation (Leeson and Summers, 2001). Feed (mash form) and water were provided ad libitum throughout the whole trial. Body weight $(\mathrm{BW}, \mathrm{g})$ and feed intake by replicate were weekly determined for all birds. Average daily gain (ADG, g/d), average daily feed intake (ADFI, g/d), and feed conversion ratio $(\mathrm{FCR}, \mathrm{g} / \mathrm{g})$ were then calculated. At the end of the trial

Table 2. Analyzed and calculated nutrient contents (\% on DM basis) of diets fed to broilers

\begin{tabular}{lrrr}
\hline \multirow{2}{*}{ Item } & \multicolumn{3}{c}{ Experimental diets $^{1}$} \\
\cline { 2 - 4 } & Starter & Grower & Finisher \\
\hline Chemical composition (\%) & & & \\
ME (kcal/kg) & 3,010 & 3,050 & 3,100 \\
Dry matter & 89.56 & 89.71 & 89.65 \\
Crude protein & 21.04 & 19.60 & 18.18 \\
Crude fat & 4.51 & 4.48 & 4.52 \\
Ash & 5.45 & 5.50 & 5.52 \\
Calcium & 1.05 & 0.90 & 0.85 \\
Available P & 0.50 & 0.45 & 0.42 \\
Sodium & 0.21 & 0.20 & 0.18 \\
Potassium & 0.50 & 0.40 & 0.40 \\
Lysine & 1.27 & 1.10 & 0.97 \\
Methionine & 0.47 & 0.42 & 0.36 \\
Methionine+cysteine & 0.94 & 0.84 & 0.76 \\
Threonine & 0.87 & 0.88 & 0.86 \\
Tryptophan & 0.20 & 0.18 & 0.16 \\
\hline
\end{tabular}

${ }^{1}$ Each diet contained one of the following fat sources: $\mathrm{T}=4 \%$ tallow; $\mathrm{CO}$ $=4 \%$ canola oil $; \mathrm{SFO}=4 \%$ sunflower oil; $\mathrm{TCO}=2 \%$ tallow $+2 \%$ canola oil TSFO $=2 \%$ tallow $+2 \%$ sunflower oil. 
Table 3. Growth performance of broiler chickens fed different lipid sources

\begin{tabular}{|c|c|c|c|c|c|c|c|}
\hline \multirow{2}{*}{ Item } & \multicolumn{7}{|c|}{ Experimental diets $^{1}$} \\
\hline & $\mathrm{T}$ & $\mathrm{CO}$ & SFO & TCO & TSFO & SEM & p-value \\
\hline $\mathrm{BW}$ (g/bird at $42 \mathrm{~d}$ of age) & $2,301^{\mathrm{b}}$ & $2,333^{\mathrm{b}}$ & $2,401^{\mathrm{b}}$ & $2,653^{\mathrm{a}}$ & $1,993^{\mathrm{c}}$ & 46.9 & 0.039 \\
\hline BW gain $(\mathrm{g} / \mathrm{d} / \mathrm{bird})$ & $54.8^{\mathrm{b}}$ & $55.6^{\mathrm{b}}$ & $57.8^{\mathrm{b}}$ & $63.2^{\mathrm{a}}$ & $47.5^{\mathrm{c}}$ & 2.65 & 0.042 \\
\hline Feed intake (g/bird) & 4,045 & 3,981 & 3,777 & 4,036 & 4,027 & 77.3 & NS \\
\hline Feed conversion ratio $(\mathrm{g} / \mathrm{g})$ & $1.76^{\mathrm{b}}$ & $1.71^{\mathrm{b}}$ & $1.57^{\mathrm{ab}}$ & $1.52^{\mathrm{a}}$ & $2.02^{\mathrm{c}}$ & 0.027 & 0.009 \\
\hline
\end{tabular}

${ }^{1} \mathrm{~T}=4 \%$ tallow; $\mathrm{CO}=4 \%$ canola oil; $\mathrm{SFO}=4 \%$ sunflower oil; $\mathrm{TCO}=2 \%$ tallow $+2 \%$ canola oil; $\mathrm{TSFO}=2 \%$ tallow $+2 \%$ sunflower oil.

${ }^{\mathrm{a}-\mathrm{c}}$ Means within treatment with no common superscript differ significantly. NS = Not significant.

(42 d of age), after a feed withdrawal period of $12 \mathrm{~h}$, a total of 12 broilers per treatment (three from each replicate) were selected according to average weight and slaughtered by cervical dislocation to determine carcass traits (weight and yield) as well as intestinal measurements.

\section{Statistical analysis}

Data were analyzed using the ANOVA option of the general linear model of SPSS software as a completely randomized design with the dietary fat sources as main effect. When there was a significant F-value, means were compared by the Tukey's method. Significance implies $\mathrm{p}<0.05$ unless stated otherwise.

\section{RESULTS}

The effects of dietary fat source on final BW, daily BW gain, cumulative feed intake and FCR are presented in Table 3. Broilers in TCO group significantly exhibited a higher final BW at $42 \mathrm{~d}$ as well as daily gains $(\mathrm{p}<0.05)$ and FCR ( $p<0.01)$ compared to the other groups. Furthermore, during the whole feeding period the cumulative feed intake of broilers did not vary significantly ( $p>0.05$ ) among groups. According to the data on Table 4, some carcass traits were influenced by dietary treatments. A significant $(\mathrm{p}<0.001)$ reduction of abdominal fat pad yield and percentage was observed in birds fed SFO diet compared to the other dietary groups. In addition, the same dietary treatment led to a better breast yield. Further, supplementation of the diets with TCO and TSFO resulted in heavier breast and drumstick meat $(\mathrm{p}<0.05$ and $\mathrm{p}<0.01$, respectively). Values for selected internal organ parameters in birds fed the experimental diets are given in Table 5. In general, dietary fat sources did not affect any of the productive performance traits studied, except for pancreas weight that tended $(\mathrm{p}<0.05)$ to be lower in broilers fed CO and TSFO diets than in birds fed the other diets. The pancreas percentage that resulted was higher $(\mathrm{p}<0.05)$ in the group fed $\mathrm{T}$ diet. When fed TSFO diet, broilers had a lighter full gizzard weight $(\mathrm{p}<0.01)$ and proventriculus weight and percentage $(\mathrm{p}<0.05)$, compared to the other dietary treatments. No statistical effects of treatments were observed on small intestine measurements of broilers, except for duodenum and ileum length that was higher $(\mathrm{p}<0.01$ and $\mathrm{p}<0.05$, respectively) in birds fed T, CO and TSFO diets compared to SFO and TCO groups (Table 6).

\section{DISCUSSION}

In this study, diet supplementation with a fat source, particularly combining $2 \%$ tallow and $2 \%$ canola oil, improved body weight and feed efficiency of broilers. The favorable results of TCO diet on growth performance of birds could be explained by the positive impact of this fat

Table 4. Carcass yield and traits of broiler chickens fed different lipid sources

\begin{tabular}{|c|c|c|c|c|c|c|c|}
\hline \multirow{2}{*}{ Item } & \multicolumn{7}{|c|}{ Experimental diets $^{1}$} \\
\hline & $\mathrm{T}$ & $\mathrm{CO}$ & SFO & TCO & TSFO & SEM & p-value \\
\hline Full carcass weight (g) & 1,805 & 1,774 & 1,835 & 2,019 & 1,970 & 51.6 & NS \\
\hline Empty carcass weight (g) & 1,295 & 1,301 & 1,395 & 1,505 & 1,533 & 49.2 & NS \\
\hline Eviscerated carcass (\%) & 66.7 & 67.1 & 69.9 & 67.5 & 69.5 & 0.77 & NS \\
\hline Breast weight (g ) & $486^{\mathrm{b}}$ & $445^{\mathrm{b}}$ & $515^{\mathrm{ab}}$ & $557^{\mathrm{a}}$ & $522^{\mathrm{ab}}$ & 27.2 & 0.041 \\
\hline Breast yield $(\%)$ & $24.2^{\mathrm{ab}}$ & $22.9^{\mathrm{b}}$ & $25.8^{\mathrm{a}}$ & $25.0^{\mathrm{ab}}$ & $24.8^{\mathrm{ab}}$ & 0.41 & 0.027 \\
\hline Drumstick weight (g) & $420^{\mathrm{ab}}$ & $365^{\mathrm{b}}$ & $429^{\mathrm{ab}}$ & $472^{\mathrm{ab}}$ & $488^{\mathrm{a}}$ & 23.9 & 0.044 \\
\hline Drumstick yield (\%) & 22.8 & 18.6 & 22.5 & 21.2 & 22.0 & 0.46 & NS \\
\hline Wings weight (g) & $127^{\mathrm{b}}$ & $121^{\mathrm{b}}$ & $134^{\mathrm{ab}}$ & $134^{\mathrm{ab}}$ & $142^{\mathrm{a}}$ & 7.9 & 0.035 \\
\hline Wings yield (\%) & 6.6 & 6.3 & 6.8 & 6.0 & 6.3 & 0.12 & NS \\
\hline Abdominal fat weight & $43.4^{\mathrm{c}}$ & $19.8^{\mathrm{b}}$ & $15.1^{\mathrm{a}}$ & $26.1^{\mathrm{c}}$ & 25.3 & 0.62 & 0.008 \\
\hline Abdominal fat yield $(\%)$ & $2.21^{\mathrm{b}}$ & $1.01^{\mathrm{ab}}$ & $0.75^{\mathrm{a}}$ & $2.28^{\mathrm{b}}$ & $2.61^{\mathrm{b}}$ & 0.13 & $<0.001$ \\
\hline
\end{tabular}

\footnotetext{
${ }^{1} \mathrm{~T}=4 \%$ tallow; $\mathrm{CO}=4 \%$ canola oil; $\mathrm{SFO}=4 \%$ sunflower oil; $\mathrm{TCO}=2 \%$ tallow $+2 \%$ canola oil; $\mathrm{TSFO}=2 \%$ tallow $+2 \%$ sunflower oil.
}

${ }^{\mathrm{a}-\mathrm{c}}$ Means within treatment with no common superscript differ significantly. NS = Not significant. 
Table 5. Carcass parameters of broiler chickens fed different lipid sources

\begin{tabular}{|c|c|c|c|c|c|c|c|}
\hline \multirow{2}{*}{ Item } & \multicolumn{7}{|c|}{ Experimental diets $^{1}$} \\
\hline & $\mathrm{T}$ & $\mathrm{CO}$ & SFO & TCO & TSFO & SEM & p-value \\
\hline Liver weight (g) & 58.1 & 64.0 & 49.9 & 60.1 & 56.5 & 4.21 & NS \\
\hline Liver $(\%)$ & 3.0 & 2.3 & 2.5 & 2.7 & 2.6 & 0.05 & NS \\
\hline Pancreas weight (g) & $9.12^{\mathrm{c}}$ & $5.51^{\mathrm{a}}$ & $6.98^{\mathrm{b}}$ & $6.80^{\mathrm{b}}$ & $5.32^{\mathrm{a}}$ & 0.12 & 0.021 \\
\hline Pancreas $(\%)$ & $0.48^{\mathrm{b}}$ & $0.29^{\mathrm{a}}$ & $0.34^{\mathrm{a}}$ & $0.30^{\mathrm{a}}$ & $0.35^{\mathrm{a}}$ & 0.01 & 0.025 \\
\hline Full gizzard weight (g) & $61.5^{\mathrm{ab}}$ & $68.8^{\mathrm{b}}$ & $64.3^{\mathrm{ab}}$ & $71.7^{\mathrm{b}}$ & $52.1^{\mathrm{a}}$ & 4.23 & 0.007 \\
\hline Full gizzard $(\%)$ & 3.2 & 3.6 & 3.3 & 3.2 & 3.0 & 0.51 & NS \\
\hline Heart weight (g) & 11.7 & 11.3 & 11.1 & 12.4 & 15.3 & 1.44 & NS \\
\hline Heart (\%) & 0.60 & 0.58 & 0.55 & 0.55 & 0.69 & 0.02 & NS \\
\hline Kidney weight (g) & 9.4 & 11.0 & 7.9 & 13.9 & 12.9 & 2.12 & NS \\
\hline Kidney $(\%)$ & 0.48 & 0.75 & 0.40 & 0.62 & 0.59 & 0.02 & NS \\
\hline Proventiculus weight (g) & $10.4^{\mathrm{b}}$ & $11.9^{\mathrm{c}}$ & $8.0^{\mathrm{b}}$ & $9.4^{\mathrm{b}}$ & $7.2^{\mathrm{a}}$ & 1.61 & 0.028 \\
\hline Proventiculus $(\%)$ & $0.54^{\mathrm{b}}$ & $0.60^{\mathrm{b}}$ & $0.40^{\mathrm{b}}$ & $0.42^{\mathrm{b}}$ & $0.32^{\mathrm{a}}$ & 0.01 & 0.033 \\
\hline
\end{tabular}

${ }^{1} \mathrm{~T}=4 \%$ tallow; $\mathrm{CO}=4 \%$ canola oil; $\mathrm{SFO}=4 \%$ sunflower oil; $\mathrm{TCO}=2 \%$ tallow $+2 \%$ canola oil; $\mathrm{TSFO}=2 \%$ tallow $+2 \%$ sunflower oil.

${ }^{\mathrm{a}-\mathrm{c}}$ Means within treatment with no common superscript differ significantly. NS = Not significant.

sources combination on the reduced passage rate of the digesta through the gastrointestinal trait, allowing for better nutrient absorption and utilization (Latshaw, 2008), resulting in a more efficient use of nutrients from diet. It has been previously reported that dietary supplementation with vegetable or animal fats did not affect feed passage rate through the digestive tract in Leghorn chickens (Golian and Polin, 1984). However, the dissimilarity of this statement with our results could be attributed to the differences in dietary fat source and especially to the birds age.

One of the main concerns relative to dietary fat supplementation is the actual metabolizable energy (ME) value that can be assigned to each fat source. In fact, the improvement in utilization of dietary fat components in birds is enhanced by different sources regardless of ME content (Jeffri et al., 2010). Early research on use of fats in poultry diets indicated a higher ME value for plant-derived oils when compared to animal sources with high free fatty acid content (Waldroup et al., 1995). Nevertheless, many experiments indicated no difference in broilers' growth performance parameters when different fat sources were fed (Pesti et al., 2002; Ghazalah et al., 2008; Mohammadi et al., 2011).

During the whole feeding period, no marked differences were observed in the feed intake of birds among groups; thus, this could indicate that the improvement in BW may have partially been due to improved nutrient digestibility and better nutrient absorption as reflected by improved feed efficiency. It was found that, broilers fed diets containing two different forms of canola oil showed a better growth

Table 6. Intestinal measurements of broiler chickens fed different lipid sources

\begin{tabular}{|c|c|c|c|c|c|c|c|}
\hline \multirow{2}{*}{ Item } & \multicolumn{7}{|c|}{ Experimental diets $^{1}$} \\
\hline & $\mathrm{T}$ & $\mathrm{CO}$ & $\mathrm{SFO}$ & TCO & TSFO & SEM & p-value \\
\hline \multicolumn{8}{|l|}{ Duodenum } \\
\hline Weight (g) & 29.07 & 30.45 & 31.25 & 32.18 & 24.95 & 1.71 & NS \\
\hline Length (cm) & $41.01^{\mathrm{a}}$ & $41.25^{\mathrm{a}}$ & $47.03^{b}$ & $48.51^{b}$ & $45.05^{\mathrm{a}}$ & 1.81 & 0.005 \\
\hline Width (mm) & 9.64 & 10.94 & 9.82 & 9.21 & 9.54 & 0.33 & NS \\
\hline Yield (\%) & 1.50 & 1.57 & 1.55 & 1.44 & 1.20 & 0.09 & NS \\
\hline \multicolumn{8}{|l|}{ Jejunum } \\
\hline Weight (g) & 122.7 & 109.3 & 125.6 & 121.1 & 127.1 & 10.03 & NS \\
\hline Length $(\mathrm{cm})$ & 15.50 & 14.25 & 14.75 & 15.51 & 13.53 & 5.65 & NS \\
\hline Width (mm) & 14.28 & 11.72 & 11.83 & 14.68 & 16.67 & 1.39 & NS \\
\hline Yield (\%) & 5.19 & 6.09 & 6.11 & 5.78 & 6.08 & 0.25 & NS \\
\hline \multicolumn{8}{|l|}{ Ileum } \\
\hline Weight (g) & 13.61 & 14.05 & 13.98 & 14.34 & 16.36 & 1.31 & NS \\
\hline Length $(\mathrm{cm})$ & $21.75^{\mathrm{a}}$ & $25.08^{\mathrm{a}}$ & $20.75^{b}$ & $22.25^{\mathrm{b}}$ & $23.50^{\mathrm{a}}$ & $0.91^{\mathrm{a}}$ & 0.026 \\
\hline Width (mm) & 10.81 & 8.71 & 11.32 & 11.01 & 11.74 & 0.41 & NS \\
\hline Yield $(\%)$ & 0.70 & 0.74 & 0.70 & 0.64 & 0.75 & 0.03 & NS \\
\hline
\end{tabular}

\footnotetext{
${ }^{1} \mathrm{~T}=4 \%$ tallow; $\mathrm{CO}=4 \%$ canola oil; $\mathrm{SFO}=4 \%$ sunflower oil; $\mathrm{TCO}=2 \%$ tallow $+2 \%$ canola oil; $\mathrm{TSFO}=2 \%$ tallow $+2 \%$ sunflower oil.
}

${ }^{\mathrm{a}-\mathrm{b}}$ Means within treatment with no common superscript differ significantly. NS = Not significant. 
rate when compared to females fed diets containing tallow and acidulated soybean oil soapstock (Gallardo et al., 2012). This observation confirms the advantage of using vegetable oils instead of tallow and acidulated soybean oil soapstock as energy sources for birds. The improved growth rate is a result from the higher percentage of long chain fatty acids and higher contents of triglycerides (Thacker et al., 1994).

Our findings are in part consistent with Andreotti et al. (2001) who showed similar performance, carcass yield and cut yields of broilers at 49 days old fed diets supplemented with poultry fat, canola, sunflower, corn, soybean or lard. According to Sanz et al. (2000), the utilization of a source of unsaturated lipids reduces fat and increases protein on broiler carcasses. The same authors evaluated inclusion levels of $8 \%$ of two lipid sources, one saturated (beef tallow) and one unsaturated (sunflower oil), reporting that there was a significant reduction in the abdominal fat of birds fed diets with sunflower oil.

In our study, carcass yield and most of organ relative weights were not affected by using different fat sources, except for abdominal fat pad production that tended to be lower in birds fed $4 \%$ of sunflower oil. Conversely, the inclusion at $4 \%$ level of tallow and canola oil combination resulted in a significant increased of breast and drumstick production. Crespo and Esteve-Garcia (2000) suggested that reduction of abdominal fat in broilers fed a diet supplemented with oil seems to be a consequence of higher lipid oxidation despite the higher synthesis of endogenous fatty acids. Among available fat sources in poultry nutrition, it has been recognized that canola oil is an adequate combination of essential fatty acids, unsaturated fatty acids (such a linolenic acid) that can improve broiler performance, and also linolenic acid can be converted to longer chain omega-3 fatty acids that is an important factor in animal feeding as health promoter (Bezard et al., 1994). Shahryar et al. (2011) found that the addition $6 \%$ animal fat caused a significant increase of abdominal fat weight compared to control unsupplemented groups. Moreover, adding 3\% of canola oil and poultry fat mixture resulted in significant enhancement in organs' weight, whereas no differences were found in liver, breast, thigh weights between groups fed fat in comparison with control group.

The findings of the present study indicated that, the length of duodenum and ileum of broilers was significantly higher when the diet contained a $4 \%$ level of tallow and canola oil combination. This increase in small intestine length disagrees with the report of Ahmad et al. (2006); these authors reported that the length of intestinal tract was reduced in birds fed a fat supplemented ration. They also stated that this result may be an adjustment of body as a result of the addition of fat in ration, which may have reduced the rate of food passage in the elementary tract (Mateos et al., 1982).
In conclusion, from our findings it seems that the supplementation of a combination of tallow with canola or sunflower oil in broiler diet could produce better performance and carcass efficiency, resulting in the highest breast and drumstick meat yields.

\section{ACKNOWLEDGEMENTS}

This manuscript was obtained from the MSc Thesis of Mohammadreza Poorghasemi at Islamic Azad University, Rasht Branch, Rasht, Iran. We are grateful to the Islamic Azad University, Rasht Branch, Rasht, Iran for support.

\section{REFERENCES}

Ahmad, F., S. Mahmood, Zia-Ur-Rehman, M. Ashraf, M. Alam and A. Muzaffar. 2006. Effect of feeding management on energy, protein intake and carcass characteristics of broilers during summer. Int. J. Agric. Biol. 8:546-549.

Andreotti, M. O., O. M. Junqueira, L. C. Cancherini, E. A. Rodrigues and N. K. Sakomura. 2001. Valor nutricional de algumas fontes de gordura para frangos de corte. In: Anais da 38th Reunião Anual da Sociedade Brasileira de Zootecnia, Piracicaba, SP. Piracicaba, SBZ.

AOAC. 2000. International. Official Methods of Analysis of AOAC International. 17th ed. AOAC Int., Arlington, VA, USA.

Baião, N. C. and L. J. C. Lara. 2005. Oil and fat in broiler nutrition. Braz. J. Poult. Sci. 1:129-141.

Bezard, J., J. P. Blond, A. Bernard and P. Clouet. 1994. The metabolism and availability of essential fatty acids in animal and human tissues. Reprod. Nutr. Dev. 34:539-568.

Celebi, S. and N. Utlu. 2004 Laying performance, serum lipoproteins, cholesterol and triglyceride of hens as influenced by dietary fat sources. J. Appl. Anim. Res. 25:121-124.

Crespo, N. and E. Esteve-Garcia. 2002. Nutrient and fatty acid deposition in broilers fed different fatty acid profiles. Poult. Sci. 81:1533-1542.

Ferrini, G., M. D. Baucells, E. Esteve-Garcia and A. C. Barroeta. 2008. Dietary polyunsaturated fat reduces skin fat as well as abdominal fat in broiler chickens. Poult. Sci. 87:528-535.

Gallardo M. A., D. D. Perez and F. M. Leighton. 2012. Modification of fatty acid composition in broiler chickens fed canola oil. Biol. Res. 45:149-161.

Ghazalah A. A., M. O. Abd-Elsamee and A. M. Ali. 2008. Influence of dietary energy and poultry fat on the response of broiler chicks to heat therm. Int. J. Poult. Sci. 7:355-359.

Golian, A. and D. Polin. 1984. Passage rate of feed in very young chicks. Poult. Sci. 63:1013-1019.

Jeffri, D., H. Firman and A. Kamyab. 2010. Comparison of soybean oil with an animal/vegetable blend at four energy levels in broiler rations from hatch to market. Int. Poult. Sci. 9:1027-1030.

Latshaw, J. D. 2008. Daily energy intake of broiler chickens is altered by proximate nutrient content and form of the diet. Poult. Sci. 87:89-95.

Laudadio, V., A. Dambrosio, G. Normanno, R. U. Khan, S. Naz, E. Rowghani and V. Tufarelli. 2012. Effect of reducing dietary 
protein level on performance responses and some microbiological aspects of broiler chickens under summer environmental conditions. Avian Biol. Res. 5:88-92.

Leeson, S. and J. D. Summers. 2001. Nutrition of the chicken. 4th ed. Ontario, University Books, p. 413.

Mateos, G. G., J. L. Sell and J. A. Eastwood. 1982. Rate of food passage as influenced by level of supplemental fat. Poult. Sci. 61:94-100.

Mohammadi, M., A. Lavvaf, E. Hajian and V. Jaberzadeh. 2011. The effect of different levels of poultry by product meal on carcass quality in broiler. Res. Opin. Anim. Vet. Sci. 1:697-699.

National Research Council. 1994. Nutrient requirements of poultry. National Academic Press, Washington, DC, USA.

Newman, R. E., W. L. Bryden, E. Fleck, J. R. Ashes, W. A. Buttemer, L. H. Storlien and J. A. Downing. 2002. Dietary n-3 and $n-6$ fatty acids alter avian metabolism: molecular-species composition of breast-muscle phospholipids. Br. J. Nutr. 88:19-28.

Peebles, E. D., C. D. Zumwalt, S. M. Doyle, P. D. Gerard, M. A. Latour, C. R. Boyle and T. W. Smith. 2000. Effects of breeder age and dietary fat source and level on broiler hatching egg characteristics. Poult. Sci. 79:698-704.

Pesti, G. N., R. I. Bakalli, M. Qiao and K. G. Sterling. 2002. A comparison of eight grades of fats as broiler feed ingredients. Poult. Sci. 81:382-390.
Sanz, M., A. Flores, D. E. Perez, P. Ayala and C. J. Lopez-Bote. 1999. Higher lipid accumulation in broilers fed on saturated fats than in those fed unsaturated fats. Br. Poult. Sci. 40:95-101.

Sanz, M., A. Flores and C. J. Lopez-Bote. 2000. The metabolic use of energy from dietary fat in broilers is affected by fatty acid saturation. Br. Poult. Sci. 41:61-68.

Shahryar, H. A., R. Salamatdoustnobar, A. Lak and A. R. Lotfi. 2011. Effect of dietary supplemented canola oil and poultry fat on the performance and carcass characterizes of broiler chickens. Curr. Res. J. Biol. Sci. 3:388-392.

Snaz, M., C. J. Lopez-Bote, D. Menoyo D. and J. M. Bautista. 2000. Abdominal fat deposition and fatty acid synthesis are lower and $\beta$-oxidation is higher in broiler chickens fed diets containing unsaturated rather than saturated fat. J. Nutr. 130:3034-3037.

Thacker, P. A., G. L. Campbell and Y. Xu. 1994. Composition and nutritive value of acidulated fatty acids, degummed canola oil and tallow as energy sources for starting broiler chicks. Anim. Feed Sci. Technol. 46:251-260.

Waldroup, P. W., S. E. Watkins and E. A. Saleh. 1995. Comparison of 2 blended animal-vegetable fats having low or high free fatty acid content. J. Appl. Poult. Res. 4:41-48.

Wongsuthavas, S., S. Terapuntuwat, W. Wongsrikeaw, S. Katawatin, C. Yuangklang and A. C. Beynen. 2008. Influence of amount and type of fat deposition, adipocyte count and iodine number of abdominal fat in broiler chickens. J. Anim. Physiol. Anim. Nutr. 92:92-98. 